U.S. Department of the Interior

Bureau of Land Management

Wyoming State Office

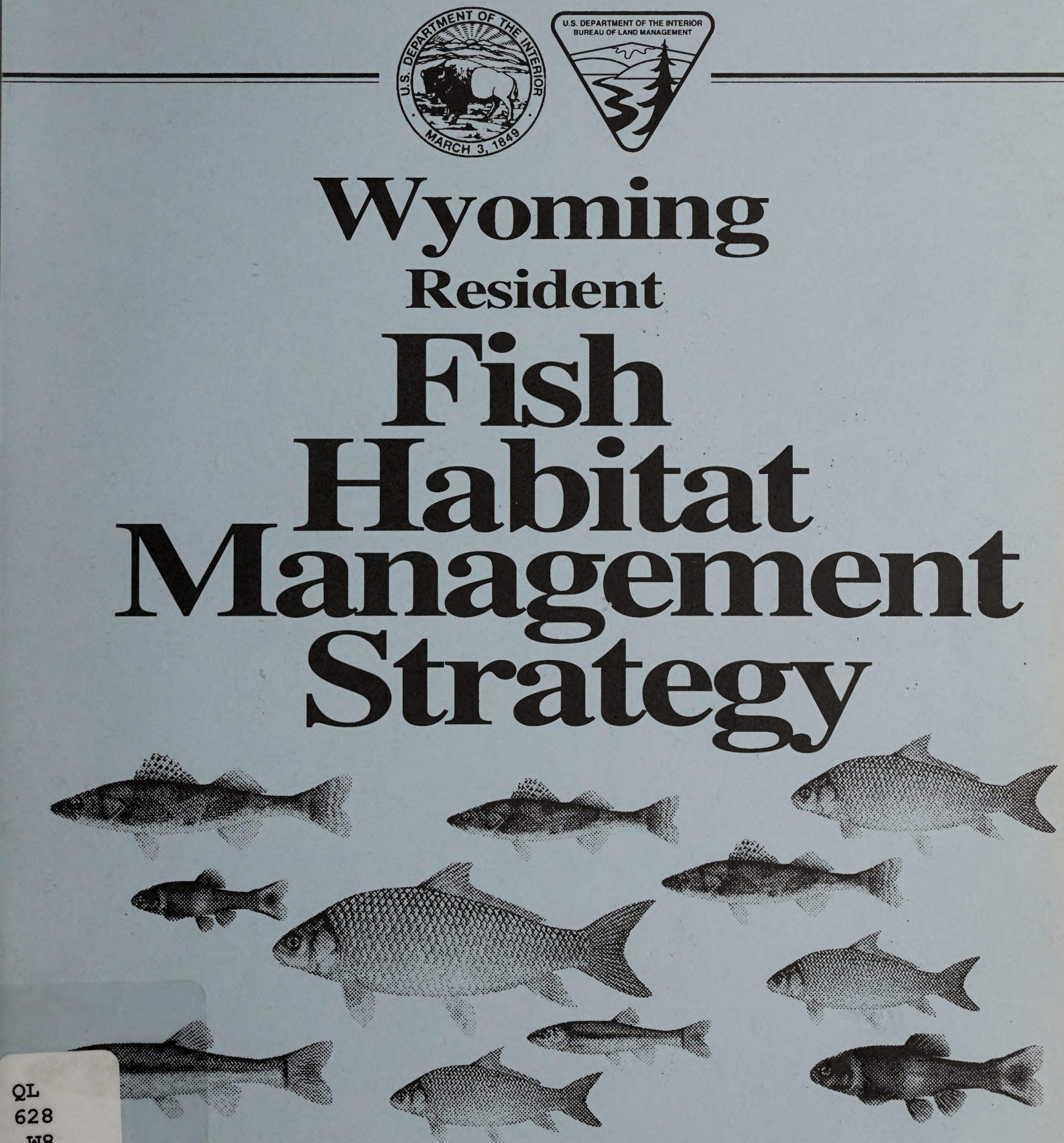





\title{
Resident Fish Habitat Management Strategy for Wyoming
}

\section{U.S. Department of the Interior Bureau of Land Management Wyoming State Office}

\author{
prepared by
}

Mark Gorges

Fisheries Biologist

BLM Library

Denver Federal Center

Bldg. 50, OC-521

P.O. Box 25047

Denver, CO 80225 


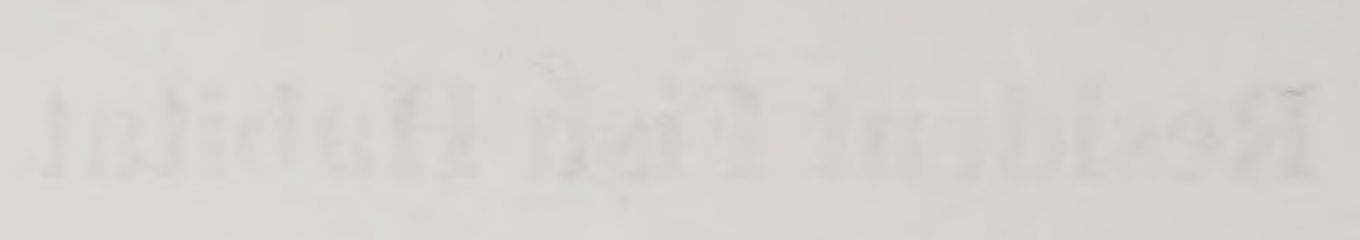

thas

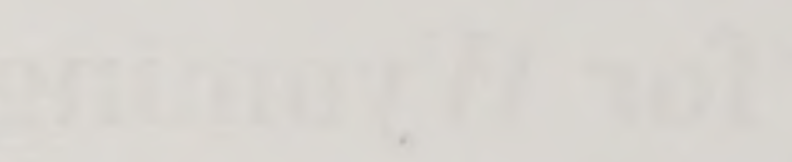




\section{State Director's Preface}

The Bureau of Land Management (BLM) manages approximately 2,000 miles of streams and 6,500 acres of surface water known to support resident fish species in Wyoming.

BLM has developed a strategic plan titled Fish and Wildlife 2000 - A Plan for the Future, which establishes goals and objectives for the management of fish, wildlife, and special status plant resources. Supplementing Fish and Wildlife 2000 are a number of plans that cover a wide range of resources, such as anadromous fish, nongame migratory birds, and special status plants.

The Bureau's Resident Fish Habitat Management plan refines Fish and Wildlife 2000 resident fish goals. It describes BLM's role in river, stream, and lake ecosystem management and recommends ways to improve conservation efforts relative to resident fish. It contains many actions that will improve the resident fishery resources for the social and economic benefit of the public. In addition, the Resident Fish Habitat Management plan complements other BLM national initiatives and plans, including Range of Our Vision, Riparian-Wetland Initiative for the 1990's, and Recreation 2000.

This Resident Fish Habitat Management Strategy for Wyoming emphasizes the importance and benefits of the proper management of resident fishery resources on public lands in Wyoming. In addition, it lists specific strategies for implementing and meeting the objectives of both the National and the Wyoming resident fish habitat plans.

For any resource management program to be successful, we must have healthy ecosystems. This can come about only by managing BLM lands in concert with other Federal, State, and local agencies, partners, and interested individuals. Resident fishery resources are an important component of the ecosystems in which they occur. This plan provides guidance and encourages cooperative management for these resources on an ecosystem basis.

I strongly endorse this plan and the ecosystem management direction it takes in managing resident fishery resources.

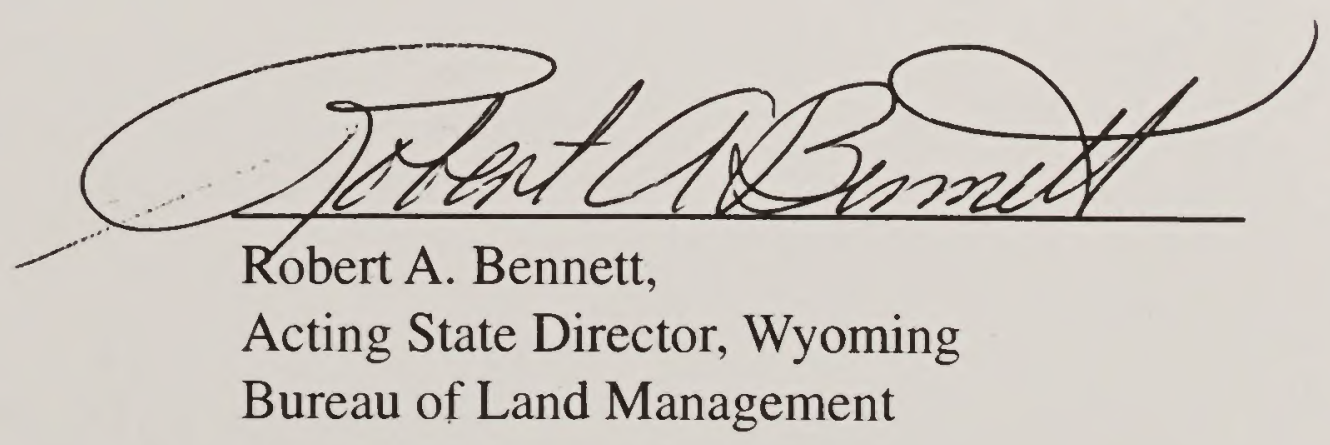





\section{Table of Contents}

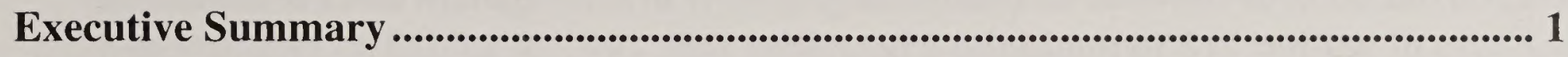

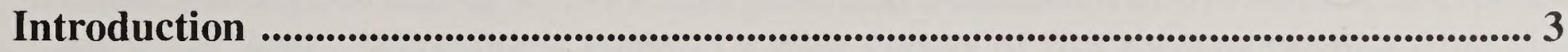

Resident Fisheries Resources ............................................................................. 5

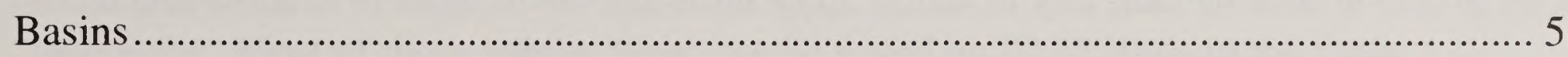

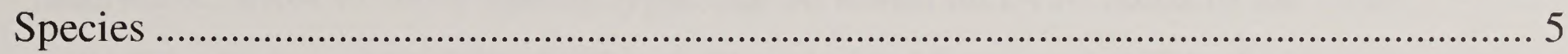

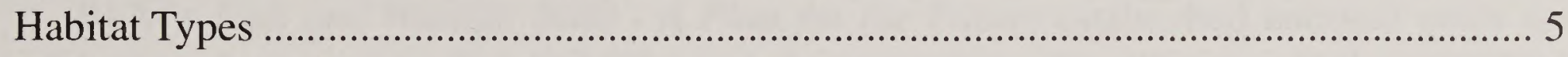

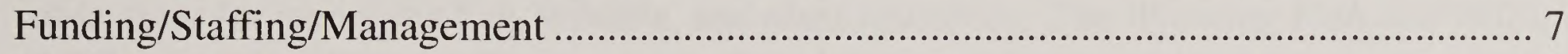

Wyoming Strategy ...................................................................................................................... 9

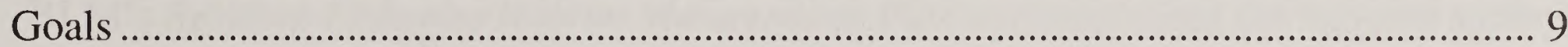

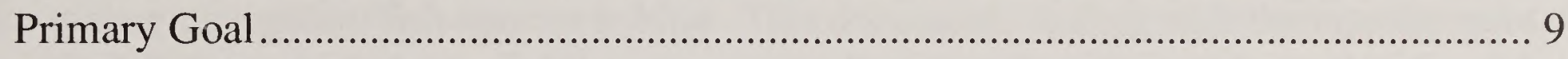

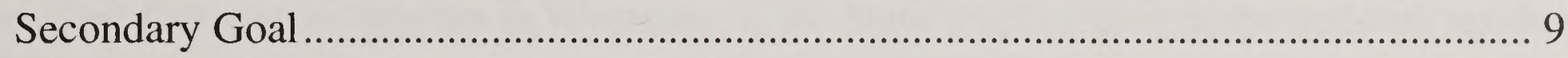

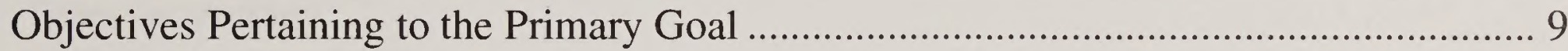

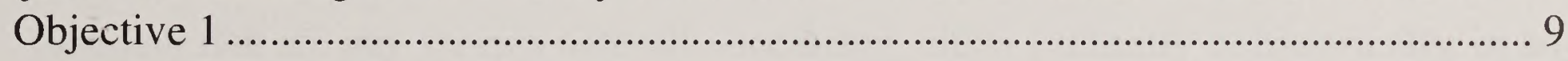

Objective 2

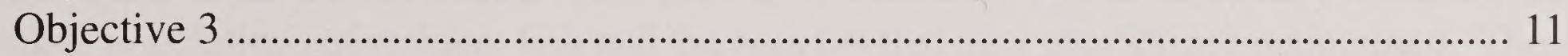

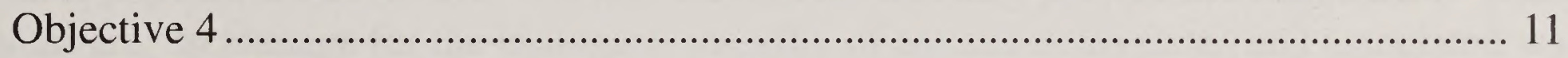

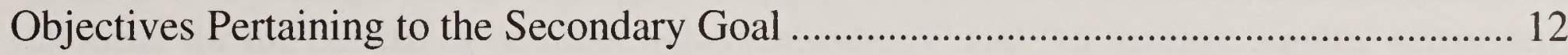

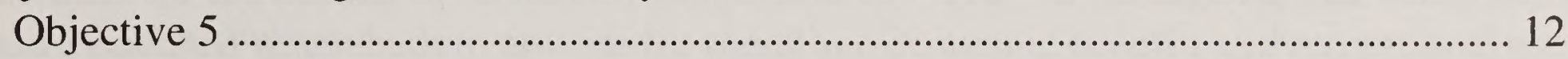

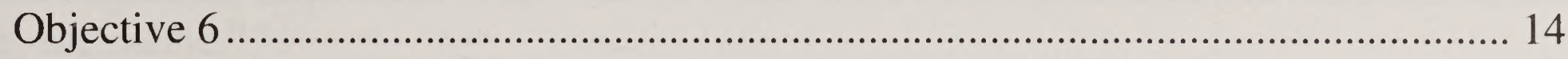

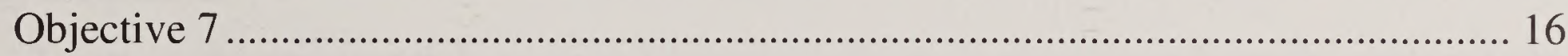

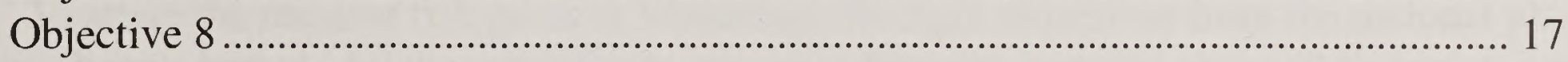

Funding and Personnel Needs .................................................................................................. 19

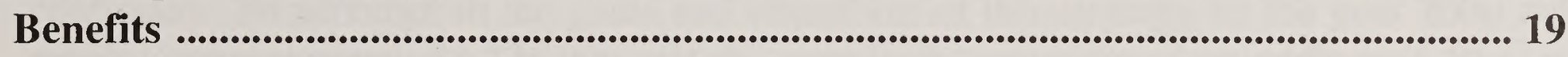

Appendix A ........................................................................................................................... 21

Resident Fish Species In Wyoming ........................................................................................ 21 



\section{Executive Summary}

The Bureau of Land Management in Wyoming accounted for between 400,000 and 600,000 recreational days of fishing in 1991; that generated a minimum of $\$ 19$ million in expenditures in the State. Wyoming is home to a wide variety of fish habitats ranging from high mountain streams to large rivers and from stock ponds of less than an acre in size to large reservoirs. Most of those habitat types can be found on BLM lands in the State.

BLM's Fish and Wildlife 2000 - A Plan for the Future established national goals and objectives for managing fish, wildlife, and plant resources. The Wyoming Fish and Wildlife 2000 - An Administrative Strategy is the State's stepped down version of the national plan. BLM's Resident Fisheries Habitat Management Plan communicated the national strategy for managing resident fish species habitat. This document, dealing with the management of resident fish species habitats in Wyoming, is the State level version of the national resident fisheries strategy.

Resident fish are any species naturally occurring, either presently or historically, in any ecosystem of the United States. This strategy identifies two goals necessary to ensure that viable populations of resident fish and the benefits that they provide are maintained. These goals are "to manage for the biological integrity of aquatic ecosystems and associated watersheds for the benefit of resident fishery resources" and "to manage aquatic ecosystems and associated watersheds to provide for social and economic benefits and recreational uses by the public."

To attain the resident fish goals in Wyoming, the eight objectives from the national plan have been adopted. All the subordinate strategies from the national plan will be initiated or continued. To accomplish the goals and objectives of this strategy by the year 2000 will require approximately $\$ 3,775,000$ and the workload equivalent of an additional 20 positions, primarily in recreation and fisheries.

The management of resident fisheries habitats in Wyoming will be part of the overall ecosystem management in the State. Ecosystem management, especially in the arid West, demands that special attention be paid to monitoring the condition of drainages and water bodies. This is a step toward assuring that those waters suitable for resident fish will be monitored and maintained in healthy ecological condition. Implementation of this strategy will ensure healthy and productive populations of resident fish. 



\section{Introduction}

The Federal Land Policy and Management Act (FLPMA) of 1976 and numerous other laws, regulations, policies, Executive orders, and Memorandums of Understanding (MOUs) direct the Bureau of Land Management (BLM) to manage its lands in a manner that will provide habitat for fish and wildlife and protect the quality of water resources. BLM has developed Fish and Wildlife 2000 - A Plan for the Future to carry out these charges. Fish and Wildlife 2000 established national goals and objectives for managing fish, wildlife and special status plant resources on BLM-administered lands. The Wyoming Fish and Wildlife 2000 - An Administrative Strategy is the State's stepped down version of the national plan.

Under the umbrella of the national Fish and Wildlife 2000, several strategies dealing with specific groups of species have been written. BLM's Resident Fisheries Habitat Management Plan is one of these management strategies. The purpose of that document was to communicate BLM's national strategy for managing resident fish species habitat. This document, dealing with the management of resident fish species habitats in Wyoming, is the State level version of the national resident fisheries strategy and is in conformance with Goal 5 (Resident Fish Species) of the Wyoming Fish and Wildlife 2000. Its purpose is to inform BLM managers and the public about the status and potential of resident fish habitats on public lands in Wyoming. BLM:

Fish species addressed in this strategy fall into the following categories as defined by

Resident Species: Any species naturally occurring, either presently or historically, in any ecosystem of the United States.

Native Species: Any species that naturally occurred within a given body of water.

Exotic Species: Any species not naturally occurring, either presently or historically, in any ecosystem of the United States. (Note: while by definition not a resident species, exotic species, like carp and brown trout, are addressed in this strategy because of their common occurrence or high recreational value.)

This document will not address in detail the needs of Special Status Species (any species listed as threatened or endangered by the Federal government or Federal candidate species.) 



\section{Resident Fisheries Resources}

BLM has management responsibility for over 2,600 miles of creeks, streams, and rivers in Wyoming, but only 1,926 miles of that are known to support resident fish species. The unaccounted for mileage may be represented by streams that have not been inventoried or small headwater stream sections which are inaccessible to fish.

BLM manages over 20,000 acres of ponds, lakes, and reservoirs in Wyoming; this includes over 4,000 livestock watering facilities. Only 6,434 of those acres are managed as sport fisheries or are known to support fish populations. Further inventory may find that there are additional ponds or reservoirs which support other fish or are suitable habitat for resident fish species.

Very little of the aquatic habitats described above is covered by specific objectives in activity plans for the management of resident fish species or their habitats.

The Wyoming Game and Fish Department's Annual Report - 1992 shows that fishing generated \$194 million in expenditures in Wyoming in 1991; there were just over 4 million recreation days of fishing in Wyoming that year. Although BLM manages approximately 30 percent of the land mass in Wyoming, much of that is uplands, and only 10 to 15 percent of the State's fishing pressure is estimated to occur on BLM lands.

\section{Basins}

Wyoming is a headwaters State; it provides water to 14 US Geological Survey (USGS) basin subregions. The following rivers, listed with their subregion designations, start or head in Wyoming:

Madison (Missouri Headwaters)

Big Horn (Big Horn)

Tongue (Powder-Tongue)

Cheyenne (Cheyenne)

Green (Great Divide-Upper Green)
Yellowstone (Upper Yellowstone)

Powder (Powder-Tongue)

Little Missouri (Missouri-Little Missouri)

Niobrara (Niobrara)

Snake (Upper Snake)

In addition, the North Platte River drains about one fourth of the State. Other tributary streams in Wyoming contribute to the South Platte, the White-Yampa, the Bear, and the Great Salt Lake subregions. Figure 1 shows the major drainages and water bodies in Wyoming.

\section{Species}

Appendix A lists all the fish species in Wyoming and the USGS basin subregions in which they occur. The State of Wyoming was home to 54 native fish species when the whiteman first arrived in the State. Twenty-one (21) additional species or hybrids have been introduced into the State. Forty-three of the native species and eight of the introduced species are known to occur in BLM waters in Wyoming.

\section{Habitat Types}

Stream habitats in Wyoming vary from large rivers like the North Platte to innumerable small headwater streams. A wide variety of manmade structures make up the majority of 


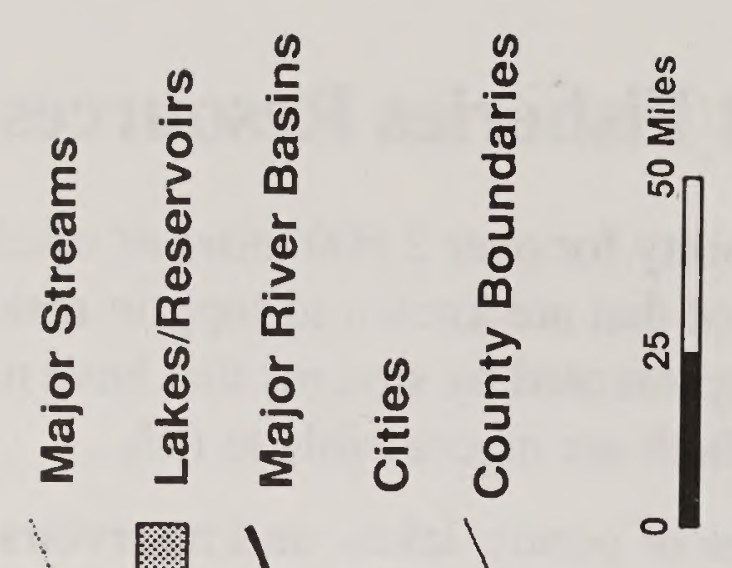

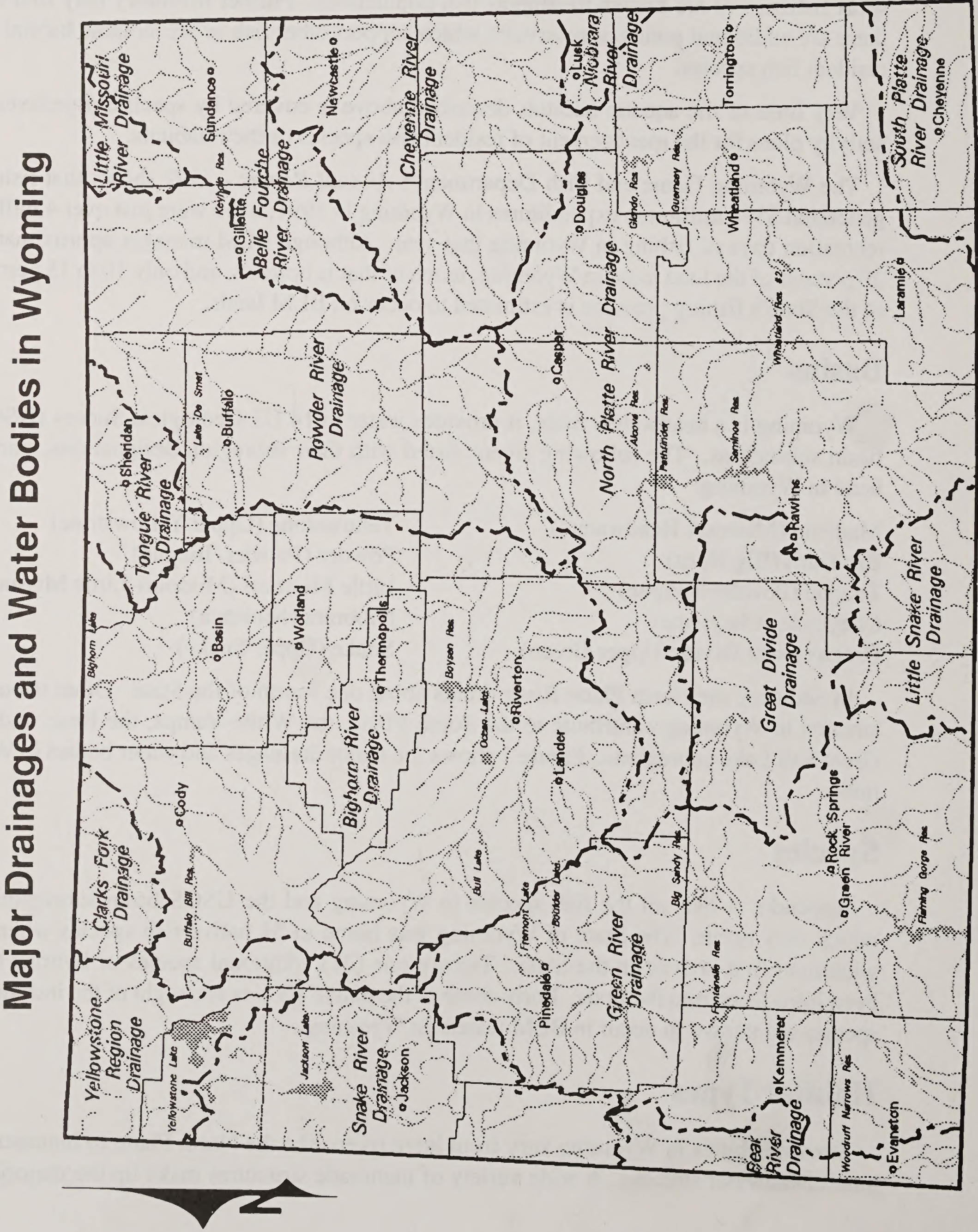


BLM lentic (nonflowing) habitats in Wyoming; these include everything from small (less than one surface acre) livestock watering structures to multi-million dollar structures for which BLM may manage only a limited number of access sites. There are very few natural lakes and ponds on BLM lands in Wyoming.

Most of the waters in Wyoming, whether natural or man-made, have been planted with or infiltrated by non-indigenous species, subspecies or hybrids. Most of the plantings have been to enhance the recreational fishing.

\section{Funding/Staffing/Management}

During the 1970's and early 1980's, extensive fisheries inventory work was done on BLM lands in Wyoming. However, the late 1980's were a low point in both funding and staffing for the entire BLM Fish and Wildlife Program, nationally and in Wyoming; for example, in 1988 there were no BLM fisheries biologists in the State. There is naturally less emphasis on the fisheries program when there is no fisheries professional on a staff. Individual wildlife biologists or others may or may not have the time, knowledge or opportunity to carry fisheries issues through planning, funding and development phases.

In 1993, there were fisheries biologists in two of the four Wyoming District Offices, a fisheries Cooperative Education Student filled a position in another District, and there. was a State Office fisheries biologist. These professionals were the catalysts for initiating fisheries planning and on the ground work on BLM lands. Increased funding generated these new fisheries staff positions, and those individuals, in turn, have further increased the funding used to address resident fisheries issues. In addition, the presence of riparian coordinators in most field offices has increased the attention given to fisheries issues as they relate to the interdisciplinary management of riparian areas.

Some of the management actions from over the last few years involving resident fisheries in Wyoming are listed below. The ten to twenty year old fisheries inventories have been updated with new inventory or monitoring data collected or acquired by BLM in specific areas throughout the State. The new data has been used to develop and update various activity plans to account for the needs of fisheries habitats. Fishing maps for use by the general public have been developed in each of the four Districts. Project funding has been enhanced through participation in the National Fish and Wildlife Foundation's "Bring Back the Natives" initiative and through cooperation with numerous local organizations such as chapters of Trout Unlimited. Close coordination with the Wyoming Game and Fish Department is a very important part of BLM's fisheries program; this includes planning, costsharing and development. Outreach activities, such as National Fishing Week celebrations, have been fostered throughout the State. Internal coordination, especially with the Recreation Program and within the Riparian Initiative, has been important to accomplish objectives within the fisheries program. 



\section{Wyoming Strategy}

The goals and objectives in this plan parallel those in the national Resident Fish Habitat Management Plan.

\section{Goals}

\section{Primary Goal}

To manage for the biological integrity of aquatic ecosystems and associated watersheds for the benefit of resident fishery resources.

\section{Secondary Goal}

To manage aquatic ecosystems and associated watersheds to provide social and economic benefits and recreational uses by the public.

To attain the resident fish goals in Wyoming, the eight objectives from the national plan have been adopted. All the subordinate strategies from the national plan will be initiated or continued. The numbers and other site specific strategies for Wyoming are presented in the following discussions for each objective. The data for the numbers in these discussions were collected in 1992 and were reviewed and were current as of January 1994.

\section{Objectives Pertaining to the Primary Goal}

\section{Objective 1}

Prioritize resident fishery resources, uses, and management opportunities.

The focus of this objective is to inventory and identify resident fishery resources, their uses, and management opportunities in order to make sound management decisions. Intensity of inventory varies based on needs. Habitat and population monitoring are needed to determine the effectiveness of management activities in achieving resident fishery resource objectives and to develop revisions to management objectives and associated actions.

\section{Strategies}

- Inventory resident fish habitats as outlined in Table 1 and provide the appropriate funding and staffing.

- In coordination with the Wyoming Game and Fish Department, monitor biological populations and their interrelated ecosystem functions to assure the maintenance of biodiversity at levels necessary for maintaining viable aquatic communities. 
Table 1

Resident Fisheries Habitat Inventory Needs - FY 95-2000

\begin{tabular}{cccccc}
\hline Fiscal Year & $\begin{array}{c}\text { Level I } \\
\text { Inventory } \\
\text { Miles/Acres }\end{array}$ & $\begin{array}{c}\text { Level II } \\
\text { Inventory } \\
\text { Miles/Acres }\end{array}$ & $\begin{array}{c}\text { LevelIII }^{\mathbf{3}} \\
\text { Inventory } \\
\text { Miles/Acres }\end{array}$ & $\begin{array}{c}\text { Work } \\
\text { Months/\# } \\
\text { New Staff }\end{array}$ & $\begin{array}{c}\text { Total Costs }^{\mathbf{4}} \\
\mathbf{( \$ 0 0 0 )}\end{array}$ \\
\hline 95 & - & $175 / 1310$ & $190 / 1600$ & $62 / 4$ & 233 \\
96 & - & $170 / 1600$ & $170 / 500$ & $58 / 3$ & 238 \\
$97-98$ & - & $100 / 610$ & $300 / 110$ & $65 / 3$ & 267 \\
$99-2000$ & - & - & $280 / 150$ & $45 / 1$ & 171 \\
\hline
\end{tabular}

${ }^{1}$ Level I provides a general description of the amount and associated values of aquatic resources and a summary of existing information. It is the minimum amount of information needed for preplanning activities for RMP's.

${ }^{2}$ Level II uses qualitative measurements to make interpretations of aquatic habitat condition based on delineated reaches. It is the minimum amount of information needed for EIS and RMP documents.

${ }^{3}$ Level III requires the use of quantitative measurements of aquatic habitat components. It is the minimum amount of information needed for activity plans.

${ }^{4}$ Total costs include work months, contracts, materials and overhead (e.g. 18\%).

\section{Objective 2}

Protect, restore, and/or enhance resident fish habitat and the ecosystem in which it occurs.

Protection, restoration, and enhancement of resident fishery resources requires ecosystem management and a recognition that anything that occurs within a particular watershed may have an impact on the water, and hence the fish, within that drainage. Planning and cooperative management agreements with other landowners are needed to eliminate conflicts or reduce impacts through avoidance, minimization of adverse impacts, compensatory actions, or other mitigation measures. Integrated activity plans are the tool used by BLM to initiate actions on the ground.

Wyoming activity plans have objectives that address the protection, restoration and/or enhancement of 77 miles and 100 acres of resident fish habitat. Of that, 54\% of that stream mileage and all of the reservoir acreage currently are meeting management objectives. However, a large portion of the fish habitat on BLM lands in Wyoming have no objectives specific to resident fish habitat management. There are currently 15 stream miles in Areas of Critical Environmental Concern (ACEC), 40 stream miles/40 surface acres in Wilderness Study Areas, and 15 stream miles that have been proposed for special designation.

\section{Strategies}

- Develop 10 new activity plans, revise 9 existing activity plans, and implement existing activity plans to protect, restore, and/or enhance resident fishery resources as listed in Table 2.

- Monitor existing plans at a level adequate to identify successes and failures and to provide the scientific data to recommend changes. 
Table 2

Resident Fisheries Activity Plans Needed - FY 93-2000

\begin{tabular}{cccccc}
\hline Fiscal Year & $\begin{array}{c}\text { Develop } \\
\text { New Plans } \\
\text { (Number) }\end{array}$ & $\begin{array}{c}\text { Revise } \\
\text { Existing Plans } \\
\text { (Number) }\end{array}$ & $\begin{array}{c}\text { Implement } \\
\text { Existing Plans } \\
\text { (Number) }\end{array}$ & $\begin{array}{c}\text { Work } \\
\text { Months }\end{array}$ & $\begin{array}{c}\text { Total Costs } \\
\mathbf{( \$ 0 0 0 )}\end{array}$ \\
\hline 95 & 5 & 1 & 11 & 26 & 151 \\
96 & 2 & 2 & 11 & 24 & 147 \\
$97-98$ & 2 & 4 & 14 & 23 & 152 \\
$99-2000$ & 1 & 2 & 13 & 19 & 244 \\
\hline
\end{tabular}

${ }^{1}$ Total costs include work months, contracts, materials and overhead (e.g. 18\%).

\section{Objective 3}

Ensure an ecosystem management approach is incorporated into existing and future management plans.

BLM fisheries management programs have traditionally focused on single species, rather than on aquatic communities. Moreover, the agency's approach to habitat has tended to focus on portions of rivers within the agency's jurisdiction, instead of an ecosystem approach that recognizes that all actions within a watershed are inextricably bound.

Scientists and managers are increasingly aware that successful management of resident fish species requires a perspective that includes, at least, entire watersheds, rather than individual reaches or artificial boundaries. Such an ecosystem approach incorporates all features of aquatic ecosystems, including physical, chemical, and biological components. Equally important, however, is the need to transcend traditional boundaries, both within the agency and among different government and private organizations.

\section{Strategies}

To ensure that the agency adopts an ecosystem approach to resident fisheries management, these concepts must be incorporated into Wyoming's 11 Land Use Plans, which include existing and proposed RMPs. Resident fisheries concerns should be addressed in all RMPs. All completed RMPs should be reviewed to ensure that resident fish concerns are addressed. These plans constitute an important opportunity to include the goals and objectives of the Resident Fish Habitat Management plan, including the strategies outlined below for ecosystem-oriented management planning.

\section{Objective 4}

Emphasize protection or restoration of native species' habitats within the historic ranges of those species.

Protection and restoration of native species is recognized by all Federal and State fisheries management agencies. Significant reductions in native fish populations and the habitat they historically occupied have been documented in all areas of the nation, but particularly in the Western States. There are two primary reasons for this downward trend:

1. Habitat degradation through human-caused impacts;

2. Introduction of exotic or nonnative fish. 
Research and management have shown that it is best to protect and maintain the natural ecosystem and leave a species in the habitat where it originally evolved. The value of a native species is often not realized or appreciated until its population has declined to the point where it no longer functions as an integral part of an ecosystem. In many cases, the value of a particular native species may simply be in the role it plays in relation to other plants and animals, or in biological terms, the ecological niche it occupies. It is for these reasons that the Bureau has supported the Bring Back the Natives initiative specifically designed to protect, maintain, and augment native fish populations. The intent of maintaining natural ecosystems is supported in several Bureau manuals.

\section{Strategies}

- Maintain or restore natural biodiversity and protect genetic integrity of native species through the use of ecosystem management concepts.

- Determine species occurrence, range of species present, historic range of species present and those extirpated.

- Assess current habitat condition, potential of the habitat given existing physical limitations, and limiting factors suppressing native fisheries.

- Protect habitat for native species by acquiring additional habitat through land exchange, retaining essential habitats in Federal ownership, encouraging the setting aside of water rights for instream flow or for fisheries purposes, and ensuring adequate water quality through control of point and nonpoint source pollution and basic watershed improvements.

\section{Objectives Pertaining to the Secondary Goal}

\section{Objective 5}

- Develop public awareness and support for resident fisheries programs and promote partnerships with other agencies, landowners, interest groups, and individuals.

An ever increasing number of people are taking part in activities related to both the consumptive and nonconsumptive use of resident fishery resources. Recreational, commercial, and subsistence use of fish and the waters they inhabit continues to rise.

BLM welcomes the multiple uses of fisheries resources on lands it manages. However, BLM realizes that effective management requires cooperation between Bureau programs and the public. Input from individuals, landowners, local governments, interest groups other Federal and State agencies, and academia, is vital to proper fisheries management. Coordinated and responsible management promotes a greater awareness and understanding of Bureau management objectives and willingness of interest groups and individuals to join with BLM in maintaining healthy fisheries.

\section{Environmental Education}

Public concern in environmental matters has led BLM to become involved in environmental education. Much of the educational thrust is directed toward the children and young adults in our schools, user groups, outdoor enthusiasts, and other interested individuals. 
Private sector partners have helped in this effort by providing funding and by developing and making fisheries related activities available to BLM. These activities are shared with school-aged children during National Fishing Week or other outdoor day programs. There are currently 3 annual educational events identified as ongoing among BLM offices in Wyoming.

\section{Outreach Partnerships}

BLM has and is developing cooperative partnerships with a variety of public land user groups and individuals as well as private companies. Potential partners include, but are not limited to: conservation groups, the recreational fishing industry, local government, private landowners, the outdoors publication industry, and nonfisheries-oriented commodity groups. These groups aid in managing fishery resources by becoming involved in rehabilitation, enhancement, access, and environmental education projects. Help comes in many forms including volunteer labor, technical knowledge, printed information, funding, access to land, and project supplies.

BLM recognizes the importance of a strong working relationship in the form of outreach partnerships. There are 2 partnership projects related to resident fisheries now in place in Wyoming. BLM has identified 29 additional plans/projects that would benefit the fishery resource and the public if implemented.

\section{Promotional Activities}

With the increasing demand for outdoor recreation, fisheries biologists, in cooperation with the recreation program and its Recreation 2000 initiative, are developing strategies to inform visitors of ways to enjoy fishery resources and to showcase projects and techniques used in day-today management.

There are 8 BLM-initiated promotional activities currently in operation. Another 14 plans/projects related to promotion are developed, but are not in operation due to funding constraints.

\section{Strategies}

- Coordinate management between BLM and other agencies and institutions through formal documents such as Memorandums of Understanding and Cooperative Agreements.

- Expand and continue to implement an Environmental Education Program that would include education activities, curriculum development, and information dissemination through guest lectures, field trips, workshops, cooperative projects, and reading material.

- Develop cooperative partnerships with concerned public land user groups, individuals, and private companies.

- Coordinate and train within BLM to promote development and use of fisheries resources. 
Table 3

Plans and/or Projects that Promote Cooperative Programs with other State Agencies, Landowners and Interest Groups for Public Support of Resident Fish

\begin{tabular}{ccccc}
\hline Plans/ & $\begin{array}{c}\text { Number } \\
\text { Currently In } \\
\text { Operation }\end{array}$ & $\begin{array}{c}\text { Number } \\
\text { Developed } \\
\text { But Not In } \\
\text { Operation }\end{array}$ & $\begin{array}{c}\text { Number In } \\
\text { Need of Review/ } \\
\text { Modification }\end{array}$ & $\begin{array}{c}\text { Number That } \\
\text { Need To Be } \\
\text { Developed Through } \\
\text { Year 2000 }\end{array}$ \\
\hline $\begin{array}{c}\text { HMP's } \\
\text { MOU's }\end{array}$ & 14 & 2 & 10 & 18 \\
$\begin{array}{c}\text { Environmental } \\
\text { Education }\end{array}$ & 8 & 1 & 1 & 9 \\
$\begin{array}{c}\text { Outreach } \\
\text { Partnership }\end{array}$ & 2 & 0 & 0 & 6 \\
$\begin{array}{c}\text { Internal } \\
\text { Promotional } \\
\text { Activities }\end{array}$ & 8 & 0 & 0 & 29 \\
Other & & 1 & 2 & - \\
RMP & - & - & 1 & - \\
AMP & 1 & - & - & 13 \\
\hline
\end{tabular}

${ }^{1}$ Environmental Education - guest lectures, field trips, workshops, outdoor days, school projects, National Fishing Week, and Educational Materials.

${ }^{2}$ Outreach Partnerships - (with private land owners-interest groups) rehabilitation, enhancement, and adopt-a-habitat.

${ }^{3}$ Internal Promotional Activities - signing, visitor centers, kiosks, watchable wildlife areas, and fishing brochures.

\section{Objective 6}

Promote existing and potential recreational and other uses and economic benefits, while ensuring protection of resident fishery resources.

Development and maintenance of recreation sites are budgeted within the Wildlife and Fisheries, Recreation Management, and Recreation Maintenance Programs. Close coordination among these programs is absolutely essential. In addition, interdisciplinary cooperation among all BLM programs (i.e., Range, Soil/Water/Air, Forestry, Minerals, etc.) is necessary to assure maintenance, protection, and enhancement of the resident fisheries habitat while providing public access.

Numerous types of recreation sites have been developed on BLM lands including: campgrounds, concessions, roads, fishing docks, interpretive signs, access stiles, access ramps, trails, viewing boxes, boat access, boat ramps, parking, day-use sites, and access for the physically challenged. However, many BLM fishing sites will remain "undeveloped", to accommodate more primitive recreational pursuits.

In Wyoming, BLM currently maintains access/campgrounds/etc., at numerous sites which promote recreational activities based on residential fishery resources. In addition, at least 23 new areas could be developed during the next six years. Approximately $\$ 317,000$ a year could be used for development, expansion, and maintenance of recreation sites during that period. 


\section{Strategies}

- Maintain existing recreational use sites as listed below:

Green River Fishing Access

New Fork River Campground

Fontenelle Res. Campground/Boat Ramp

Green River Weeping Rock Camp Ground

Green River Tail Race Campground

Green River Slate Creek Campground

Sweetwater River Access/Campground

Encampment River/Encampment

North Platte River/Bennett Peak/Corral Creek

N. Platte River/Dugway

Teton Reservoir

Goldeneye Reservoir

North Platte River/Trappers Route

Middlefork Powder River

North Fork Powder River, Red Fork Powder River, Crazywoman Cr.

Powder River, Reservoirs

- Work with interest groups to identify, develop, and expand recreation sites, including those listed below, to support the Bureau's recreational fishing policy and to accommodate growing fishing demands:

Sage Creek - Rim Lake

Baggs - Retention/Wild Horse Res.

Saratoga Valley - Encampment River

Ferris/Seminoe - N. Platte River/Dugway

Sage Creek - Teton Reservoir

Saratoga Valley - Bennett Peak

Saratoga Valley - Corral Creek

Red Desert - A \& M Reservoir

Saratoga Valley - Prospect Creek Road

Baggs - Cherokee No. 2

Meadow Draw HMP - Meadow Draw Reservoir

North Platte River RAMP - North Platte River/Trappers Route No. 1

(Possible project for Physically Challenged Anglers Fishing Platform

Bishop HMP - Casper Creek/ Bishop Water-fowl/Fisheries and Recreation

Enhancement Project

Bighorn River HMP/RAMP - Handicap access sites, Manderson area

Cody Rivers RAMP - To be written 94 . Various river tracts

West Slope Special Recreation Area Plan - S. Trapper Cr. easement

West Slope Special Recreation Area Plan - Canyon Cr. easement and site development

Boulder Lake Rec. Plan - Boulder Lake

14 Mile Rest area - 14 Mile Reservoir 


\section{Objective 7}

Secure lands and waters important to improve manageability of or access to resident fishery habitats.

BLM's land ownership pattern is often scattered (i.e., "checkerboard") and is not situated for the best management of resident fishery habitats. In some cases, private or other landowners may inhibit direct recreational or managerial access to BLM-administered lands. In addition, waters and lands in nonFederal ownership within specific watersheds may be managed for many uses, often with conflicting objectives, in ways which adversely affect fishery habitats on BLM lands.

The Bureau has many avenues to follow to assure proper management of fishery habitats on BLM-administered lands. The Bureau functions within mandated laws, regulations, and guidelines to foster multiple-use management which can protect and maintain fishery habitats. BLM can initiate partnerships and cooperative agreements with other landowners and managers to foster the enhancement or maintenance of fishery habitats. With an active Lands Program, the Bureau can initiate exchanges, easements, donations, and acquisitions of lands and water to improve manageability of resident fishery habitats. Coordination with other Federal, State, and local agencies is important to protect the rights and resources of private landowners.

The acquisition of land, water, and water rights could cost as much as $\$ 525,000$ between 1994 and 2000. This includes proposed Land \& Water Conservation Fund acquisitions. In lieu of purchasing, lands and waters can be secured through management partnerships, cooperative agreements, donations, exchanges, and easements.

\section{Strategies}

- Identify opportunities to secure lands, water, and access easements (Tables 4 and 5).

\section{Table 4}

\section{Sites Where Resident Fish, Fishing Access is Limited and What is Limiting It}

This includes such things as physically challenged access, rights-of-ways, roads, trails, docks, etc.

Estimate of funding needed to right the problem.

\begin{tabular}{|c|c|c|c|}
\hline $\begin{array}{l}\text { Activity Plan } \\
\text { Name }\end{array}$ & Water Body & Limiting Factor & Solution \\
\hline \multicolumn{4}{|l|}{ North Platte } \\
\hline River RAMP & North Platte River & Physically Challenged Access & Install Fishing Platform \\
\hline Bishop HMP & Casper Creek & Right of way access & $\begin{array}{l}\text { Obtain legal access, } \\
\text { road construction }\end{array}$ \\
\hline $\begin{array}{l}\text { South Bighorns } \\
\text { HMP }\end{array}$ & $\begin{array}{l}\text { North Fork Powder, } \\
\text { Red Fork Powder, } \\
\text { Crazywoman Cr. }\end{array}$ & Private lands, Access, Politics & $\begin{array}{l}\text { Land exchanges, easements, } \\
\text { management commitment }\end{array}$ \\
\hline $\begin{array}{l}\text { Saratoga Valley/ } \\
\text { Saga Creek }\end{array}$ & N. Platte River & Access & $\begin{array}{l}\text { Obtain public access } \\
\text { along N. Platte River }\end{array}$ \\
\hline Ferris/Seminoe & N. Platte River & Access & $\begin{array}{l}\text { Obtain public access } \\
\text { along N. Platte River }\end{array}$ \\
\hline Sage Creek & Rim Lake & Legal Access & Obtain public access \\
\hline
\end{tabular}


Table 4 (Continued)

Sites Where Resident Fish, Fishing Access is Limited and What is Limiting It

This includes such things as physically challenged access, rights-of-ways, roads, trails, docks, etc.

Estimate of funding needed to right the problem.

\begin{tabular}{|c|c|c|c|}
\hline $\begin{array}{l}\text { Activity Plan } \\
\text { Name }\end{array}$ & Water Body & Limiting Factor & Solution \\
\hline $\begin{array}{l}\text { Bighorn River } \\
\text { HMP/RAMP }\end{array}$ & Bighorn River & $\begin{array}{l}\text { Handicap access, Road access, } \\
\text { Legal access across private } \\
\text { land to BLM, putin- } \\
\text { takeout points. }\end{array}$ & $\begin{array}{l}\text { Site plans for } \\
\text { developments, easements, } \\
\text { facilities. }\end{array}$ \\
\hline $\begin{array}{l}\text { Cody RV's RAMP } \\
\text { (est. FY94) }\end{array}$ & $\begin{array}{l}\text { Shoshone, N. Fk. } \\
\text { Shoshone, S.FK. } \\
\text { Shoshone, Clark Fk. }\end{array}$ & $\begin{array}{l}\text { Road access, Legal access } \\
\text { across private land to BLM, } \\
\text { putin-takeout points. }\end{array}$ & $\begin{array}{l}\text { Site plans for } \\
\text { developments, easements, } \\
\text { facilities. }\end{array}$ \\
\hline West Slope RAMP & $\begin{array}{l}\text { S. Trapper Cr., } \\
\text { Canyon Cr. }\end{array}$ & physical and legal access & Easements \\
\hline $\begin{array}{l}\text { VARIOUS - } \\
\text { Rock Springs DO }\end{array}$ & $\begin{array}{l}\text { Fontenelle Res } \\
\text { Boulder Lake } \\
\text { New Fork Res } \\
14 \text { Mile Res }\end{array}$ & & $\begin{array}{l}\text { Handicap access could } \\
\text { be improved or created }\end{array}$ \\
\hline
\end{tabular}

Table 5

Lands and/or Waters Needed to Improve Manageability

\begin{tabular}{|c|c|c|c|}
\hline Activity Plan Name & Water Body & Need & Possible Method \\
\hline Baggs/Daley/Grizzly & McKinney/Grove/Stoney Creeks & 8,000 acres & Exchange \\
\hline Baggs/ Savery & Little Savery Creek & 12,000 acres & State/Private Exchange \\
\hline Saratoga Valley & Beaver Creek (Loco Creek) & 3,000 acres & State Exchange \\
\hline $\begin{array}{l}\text { Green River RMP, } \\
\text { Currant Creek/Sage } \\
\text { Creek HMP }\end{array}$ & Trout Creek and Currant Creek & $\begin{array}{l}\text { Private and } \\
\text { State Lands }\end{array}$ & $\begin{array}{l}\text { Exchange for stream and } \\
\text { riparian area }\end{array}$ \\
\hline South Bighorns & $\begin{array}{l}\text { North Fork Powder, Red Fork } \\
\text { Powder, Crazywoman Cr., } \\
\text { Beartrap Cr. }\end{array}$ & $\begin{array}{l}\text { Access for } \\
\text { Inventory and } \\
\text { Management. } \\
\text { Public Access. }\end{array}$ & $\begin{array}{l}\text { Management Emphasis } \\
\text { on Exchange/ Pooling }\end{array}$ \\
\hline Green River RMP & Big Sandy River & $\begin{array}{l}\text { Private and } \\
\text { State Lands }\end{array}$ & $\begin{array}{l}\text { Exchange for stream and } \\
\text { riparian area }\end{array}$ \\
\hline
\end{tabular}

\section{Objectives Pertaining to Both Goals}

\section{Objective 8}

Identify and design national and regional research and study needs, incorporating ecosystem management concepts, for the conservation and management of resident fishery resources.

BLM-administered lands in Wyoming contain many unique populations of resident fish. There are many questions that need to be answered to adequately manage them within a multiple-use scenario. Major research needs include:

- Assessing habitat requirements and life histories for resident native fish. 
- Evaluating the potential for native fish reintroduction.

- Describing fish and invertebrate communities.

- Modeling long-term effects of various land use practices.

- Identifying consequences of long-term environmental changes.

To enable integrated Bureau management teams to conserve and manage resident fish, research must answer management's current questions, provide models for new management challenges, and provide baseline data to help managers meet unspecified long-term climate and use-based changes.

Elements of resident fish research involve other agencies, partners, universities, and the public at large. Research will be undertaken in consultation and partnership with all affected entities.

Many actions currently being considered by the Bureau will assist the development of the state-by-state and Bureauwide research plans. It is assumed this research will strengthen the Bureau's anadromous and special status fish management as well as resident fish management. It is also assumed research to protect and restore native fishes will be given highest priority.

Currently, BLM has identified 6 studies in Wyoming that would require approximately $\$ 270,000$ to implement.

\section{Strategies}

- In coordination with the Wyoming Game and Fish Department, identify and prioritize research needs for native species within their historic ranges.

Table 6

\section{Research/Studies Needs for Resident Fish}

\begin{tabular}{|c|c|c|c|c|c|}
\hline $\begin{array}{l}\text { Activity } \\
\text { Plan Name }\end{array}$ & $\begin{array}{c}\text { Major } \\
\text { Watershed }\end{array}$ & $\begin{array}{l}\text { Number of } \\
\text { Studies }\end{array}$ & $\begin{array}{l}\text { Type of } \\
\text { Research/ } \\
\text { Studies }\end{array}$ & $\begin{array}{l}\text { Est. } \\
\text { WMs }\end{array}$ & $\begin{array}{l}\text { Costs } \\
(\$ 000)\end{array}$ \\
\hline $\begin{array}{l}\text { Area wide: } \\
\text { Great Divide RA }\end{array}$ & $\begin{array}{l}\text { N.Platte R. } \\
\text { S.Platte R. } \\
\text { L.Snake R. }\end{array}$ & 3 & Species distribution inventory & 6 & 100 \\
\hline $\begin{array}{l}\text { Baggs/ Savery } \\
\text { Creek }\end{array}$ & L.Snake R. & 1 & $\begin{array}{l}\text { Life History studies of species } \\
\text { of concern in L. Snake R } \\
\text { ( } 4 \text { species) }\end{array}$ & 6 & 80 \\
\hline Newcastle RA & & 1 & $\begin{array}{l}\text { Baseline inventory to determine } \\
\text { species }\end{array}$ & 10 & 10 \\
\hline $\begin{array}{l}\text { Bighorn River } \\
\text { HMP }\end{array}$ & Bighorn River & 1 & $\begin{array}{l}\text { Determine population status of } \\
\text { Sturgeon - contract or COOP } \\
\text { with WGFD or F\&WS }\end{array}$ & 6 & 80 \\
\hline TOTAL & & & & 28 & 270 \\
\hline
\end{tabular}




\section{Funding and Personnel Needs}

Through the year 2000, Wyoming BLM projects a need for the equivalent of approximately 20 new positions, primarily in recreation and fisheries, to meet the goals of the BLM's Resident Fisheries Habitat Management Plan and the Resident Fish Habitat Management Strategy for Wyoming. Together with the workmonths for existing personnel, there would be an annual expenditure of about $\$ 340,000$ for all needed labor costs. Overall, the average annual cost to fully implement the strategy in Wyoming would be about $\$ 629,000$ for a six year period; that compares to the $\$ 300,000$ to $\$ 400,000$ now being spent each year. The larger variations in expenditures from year to year would be explained by the differences in land acquisitions, project developments, and the awarding of contracts.

\section{Benefits}

Implementation of the Resident Fish Habitat Management Strategy for Wyoming will result in many benefits. The most important of these is to provide for healthy and productive populations of resident fish through incorporation of regional ecosystem management concepts. A secondary benefit is to provide public recreational fishing opportunities.

Healthy fish populations require good quality water. Meeting this requirement is facilitated by restoring and maintaining healthy riparian-wetland ecosystems. Properly functioning riparian wetland systems benefit wildlife and other aquatic organisms, filter runoff, absorb energy from floodflows, provide desirable recreation sites, etc. Proper management

of uplands in a watershed reduces siltation and nonpoint pollution sources and helps to ensure continued productivity.

Implementation of this strategy will provide recreational, economic, biological, aesthetic, and ecosystem benefits in the State of Wyoming and will enhance the values of the public lands for the American people. 



\section{APPENDIX A}

\section{Resident Fish Species In Wyoming}

(USGS Basin Subregion Codes: 1002-Missouri Headwaters; 1007-Upper Yellowstone; 1008-Big Horn; 1009-Powder-Tongue; 1011-Missouri-Little Missouri; 1012-Cheyenne; 1015-Niobrara; 1018-North Platte; 1019 South Platte; 1404-Great Divide-Upper Green; 1405-White-Yampa; 1601-Bear; 1602-Great Salt Lake; 1704-Upper Snake.)

* These species may no longer occur in these drainages.

\begin{tabular}{|c|c|c|c|}
\hline $\begin{array}{c}\text { Species } \\
\text { Common Name }\end{array}$ & Scientific Name & $\begin{array}{l}\text { Species } \\
\text { Code }\end{array}$ & $\begin{array}{c}\text { USGS Basin } \\
\text { Subregion }\end{array}$ \\
\hline Shovelnose Sturgeon & Scaphirhynchus platorynchus & SCPL & $\begin{array}{l}1008^{*} \\
1009 \\
1018 *\end{array}$ \\
\hline Gizzard Shad & Dorosoma cepedianum & DOCE & $\begin{array}{l}1018 \\
\text { Introduced } \\
1012\end{array}$ \\
\hline Goldeye & Hiodon alosoides & HIAL & $\begin{array}{l}1008^{*} \\
1009 \\
1011 \\
1018 *\end{array}$ \\
\hline Mountain Whitefish & Prosopium williamsoni & PRWI & $\begin{array}{l}1002 \\
1007 \\
1008 \\
1009 \\
1404 \\
1405 \\
1601 \\
1704\end{array}$ \\
\hline $\begin{array}{l}\text { Yellowstone Cutthroat } \\
\text { Trout (also Snake River) }\end{array}$ & Oncorhynchus clarki bourieri & SACLBO & $\begin{array}{l}1002 \\
1007 \\
1008 \\
1009 \\
1704 \\
\text { Introduced } \\
1018\end{array}$ \\
\hline $\begin{array}{l}\text { Colorado River } \\
\text { Cutthroat Trout }\end{array}$ & Oncorhynchus clarki pleuriticus & SACLPL & $\begin{array}{l}1404 \\
1405 \\
\text { Introduced } \\
1018\end{array}$ \\
\hline Grayling & Thymallus arcticus & THAR & $\begin{array}{l}1002 \\
1007 \\
\text { Introduced } \\
1008 \\
1009 \\
1404\end{array}$ \\
\hline
\end{tabular}




\section{APPENDIX A (Continued)}

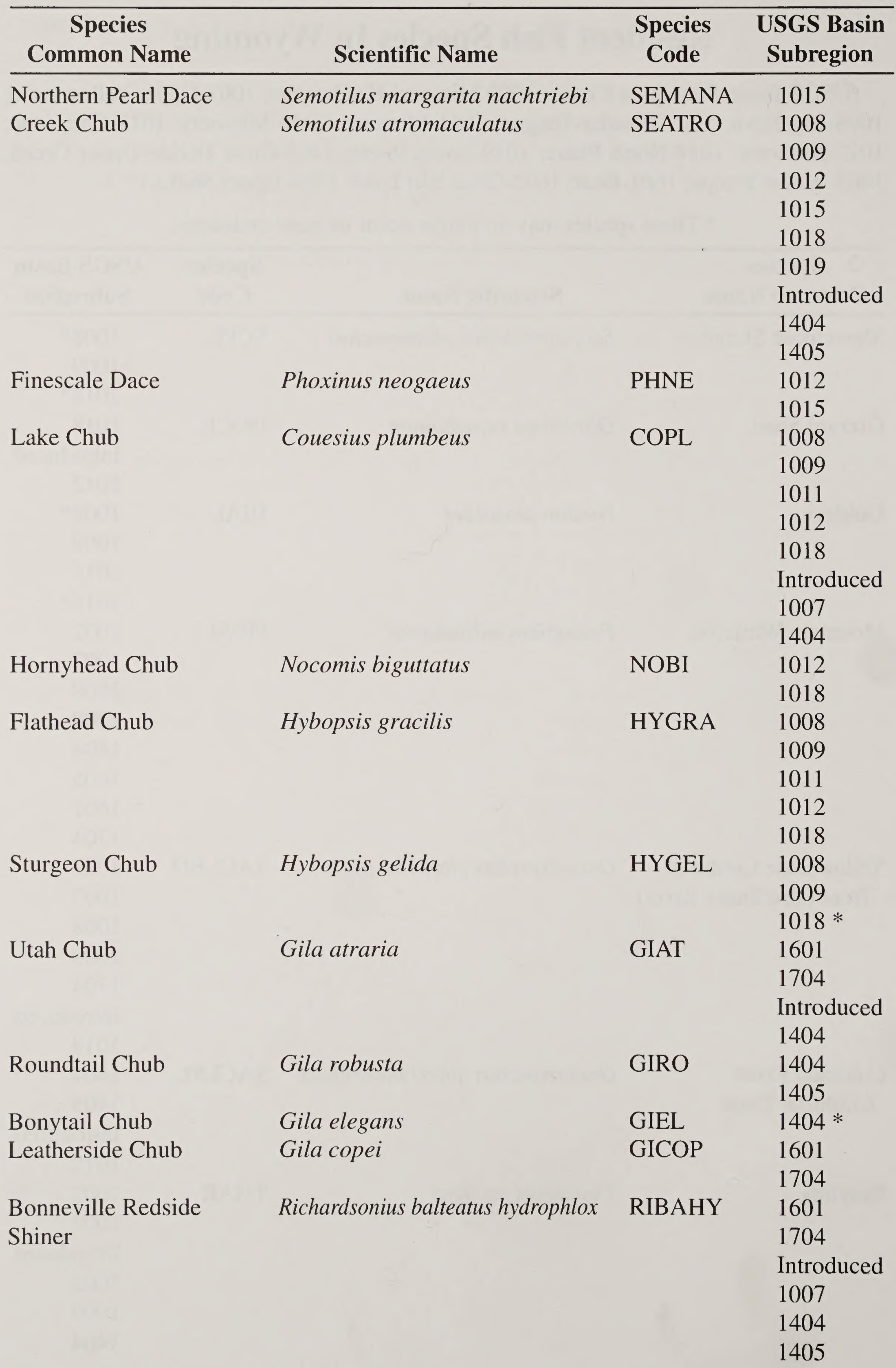


APPENDIX A (Continued)

\begin{tabular}{|c|c|c|c|}
\hline $\begin{array}{c}\text { Species } \\
\text { Common Name }\end{array}$ & Scientific Name & $\begin{array}{l}\text { Species } \\
\text { Code }\end{array}$ & $\begin{array}{c}\text { USGS Basin } \\
\text { Subregion }\end{array}$ \\
\hline Colorado Squawfish & Ptychocheilus lucius & PTLU & $1404 *$ \\
\hline Speckled Dace & Rhinichthys osculus & RHOS & $\begin{array}{l}1404 \\
1405 \\
1601 \\
1704\end{array}$ \\
\hline Longnose Dace & Rhinichthys cataractae & RHCA & $\begin{array}{l}1002 \\
1007 \\
1008 \\
1009 \\
1011 \\
1012 \\
1015 \\
1018 \\
1019 \\
1601 \\
1704 \\
\text { Introduced } \\
1404\end{array}$ \\
\hline Suckermouth Minnow & Phenacobius mirabilis & PHMIR & 1018 \\
\hline Common Shiner & Notropis cornutus & NOCOR & $\begin{array}{l}1018 \\
1019\end{array}$ \\
\hline River Shiner & Notropis blennius & NOBL & 1018 \\
\hline Red Shiner & Notropis lutrensis & NOLUT & 1018 \\
\hline Bigmouth Shiner & Notropis dorsalis & NODO & $\begin{array}{l}1018 \\
1019\end{array}$ \\
\hline Sand Shiner & Notropis stramineus missuriensis & NOSTR & $\begin{array}{l}1009 \\
1011 \\
1012 \\
1015 \\
1018 \\
1019 \\
\text { Introduced } \\
1008\end{array}$ \\
\hline Brassy Minnow & Hybognathus hankinsoni & HYHA & $\begin{array}{l}1009 \\
1011 \\
1015 \\
1018 \\
1019\end{array}$ \\
\hline Plains Minnow & Hybognathus placitus & HYPLA & $\begin{array}{l}1008 \\
1009 \\
1011 \\
1012 \\
1018\end{array}$ \\
\hline
\end{tabular}


APPENDIX A (Continued)

\begin{tabular}{|c|c|c|c|}
\hline $\begin{array}{c}\text { Species } \\
\text { Common Name } \\
\end{array}$ & Scientific Name & $\begin{array}{c}\text { Species } \\
\text { Code } \\
\end{array}$ & $\begin{array}{c}\text { USGS Basin } \\
\text { Subregion } \\
\end{array}$ \\
\hline \multirow[t]{2}{*}{ Silvery Minnow } & Hybognathus nuchalis & HYNU & $\begin{array}{l}1008 \\
1009\end{array}$ \\
\hline & & & 1011 \\
\hline \multirow[t]{8}{*}{ Fathead Minnow } & Pimephales promelas & PIPR & 1008 \\
\hline & & & 1009 \\
\hline & & & 1011 \\
\hline & & & 1012 \\
\hline & & & 1015 \\
\hline & & & 1018 \\
\hline & & & 1019 \\
\hline & & & $\begin{array}{l}\text { Introduced } \\
1404\end{array}$ \\
\hline \multirow{3}{*}{ Stoneroller } & Campostoma anomalum & CAANO & 1015 \\
\hline & & & 1018 \\
\hline & & & 1019 \\
\hline Quillback & Carpiodes cyprinus & CACY & 1018 \\
\hline \multirow[t]{5}{*}{ River Carpsucker } & Carpiodes carpio & CACAP & 1008 \\
\hline & & & 1009 \\
\hline & & & 1011 \\
\hline & & & 1012 \\
\hline & & & 1018 \\
\hline \multirow[t]{4}{*}{ Northern Redhorse } & Moxostoma macrolepidotum & MOMA & 1008 \\
\hline & & & 1009 \\
\hline & & & 1012 \\
\hline & & & 1018 \\
\hline \multirow[t]{10}{*}{ White Sucker } & Catostomus commersoni & CACOM & 1008 \\
\hline & & & 1009 \\
\hline & & & 1011 \\
\hline & & & 1012 \\
\hline & & & 1015 \\
\hline & & & 1018 \\
\hline & & & 1019 \\
\hline & & & Introduced \\
\hline & & & 1404 \\
\hline & & & 1405 \\
\hline \multirow[t]{2}{*}{ Utah Sucker } & Catostomus ardens & CAAR & 1601 \\
\hline & & & 1704 \\
\hline \multirow[t]{7}{*}{ Longnose Sucker } & Catostomиs catostomиs & CACAT & 1007 \\
\hline & & & 1008 \\
\hline & & & 1009 \\
\hline & & & 1012 \\
\hline & & & 1018 \\
\hline & & & 1019 \\
\hline & & & $\begin{array}{l}\text { Introduced } \\
1404\end{array}$ \\
\hline
\end{tabular}


APPENDIX A (Continued)

\begin{tabular}{|c|c|c|c|}
\hline $\begin{array}{c}\text { Species } \\
\text { Common Name }\end{array}$ & Scientific Name & $\begin{array}{c}\text { Species } \\
\text { Code }\end{array}$ & $\begin{array}{c}\text { USGS Basin } \\
\text { Subregion }\end{array}$ \\
\hline Flannelmouth Sucker & Catostomus latipinnis & CALA? & $\begin{array}{l}1404 \\
1405\end{array}$ \\
\hline Mountain Sucker & Catostomus platyrhynchus & CAPLA & $\begin{array}{l}1002 \\
1007 \\
1008 \\
1009 \\
1011 \\
1012 \\
1018 \text { * } \\
1404 \\
1405 \\
1601 \\
1704\end{array}$ \\
\hline Bluehead Sucker & Catostomus discobolus & CADI & $\begin{array}{l}1404 \\
1405 \\
1601 \\
1704\end{array}$ \\
\hline June Sucker & Chasmistes liorus & CHLI & $1704 *$ \\
\hline Humpback Sucker & Xyrauchen texanus & XYTE & $1404 *$ \\
\hline Black Bullhead & Ictalurus melas & ICME & $\begin{array}{l}1008 \\
1009 \\
1011 \\
1012 \\
1015 \\
1018 \\
1019\end{array}$ \\
\hline Channel Catfish & Ictalurus punctatus & ICPUN & $\begin{array}{l}1008 \\
1009 \\
1011 \\
1012 \\
1018 \\
\text { Introduced } \\
1404 \\
1405\end{array}$ \\
\hline Stonecat & Noturus flavus & NOFLAV & $\begin{array}{l}1007 \\
1008 \\
1009 \\
1012 \\
1018\end{array}$ \\
\hline Burbot & Lota lota & LOLOT & $\begin{array}{l}1008 \\
1009\end{array}$ \\
\hline
\end{tabular}


APPENDIX A (Continued)

\begin{tabular}{|c|c|c|c|}
\hline $\begin{array}{c}\text { Species } \\
\text { Common Name }\end{array}$ & Scientific Name & $\begin{array}{c}\text { Species } \\
\text { Code }\end{array}$ & $\begin{array}{c}\text { USGS Basin } \\
\text { Subregion }\end{array}$ \\
\hline Plains Topminnow & Fundulus sciadicus & FUSC & $\begin{array}{l}1015 \\
1018 \\
1019 \\
\text { Introduced } \\
1012\end{array}$ \\
\hline Plains Killifish & Fundulus kansae & FUKA & $\begin{array}{l}1008 \\
1015 \\
1018 \\
1019\end{array}$ \\
\hline Sauger & Stizos tedion canadense & STCAN & $\begin{array}{l}1008 \\
1009 \\
1018\end{array}$ \\
\hline Johnny Darter & Etheostoma nigrans & ETNIG & $\begin{array}{l}1018 \\
1019\end{array}$ \\
\hline Iowa Darter & Etheostoma exile & ETEX & $\begin{array}{l}1015 \\
1018 \\
1019\end{array}$ \\
\hline Orangethroat Darter & Etheostoma spectabile pulchellum & ETSPPU & 1019 \\
\hline Mottled Sculpin & Cottus bairdi & COBAI & $\begin{array}{l}1002 \\
1007 \\
1008 \\
1404 \\
1405 \\
1601 \\
1704\end{array}$ \\
\hline Piute Sculpin & Cottus beldingi & COBE & 1704 \\
\hline -NON-NATIVE- & & \multicolumn{2}{|c|}{ INTRODUCED } \\
\hline Kokanee Salmon & Oncorhynchus nerka & ONNE & $\begin{array}{l}1404 \\
1019\end{array}$ \\
\hline Rainbow Trout & Oncorhynchus mykiss & SAGA & $\begin{array}{l}1002 \\
1007 \\
1008 \\
1009 \\
1012 \\
1018 \\
1019 \\
1404 \\
1405 \\
1704\end{array}$ \\
\hline
\end{tabular}




\section{APPENDIX A (Continued)}

\begin{tabular}{|c|c|c|c|}
\hline $\begin{array}{c}\text { Species } \\
\text { Common Name }\end{array}$ & Scientific Name & $\begin{array}{c}\text { Species } \\
\text { Code }\end{array}$ & $\begin{array}{c}\text { USGS Basin } \\
\text { Subregion }\end{array}$ \\
\hline Brown Trout & Salmo trutta & SATR & $\begin{array}{l}1002 \\
1007 \\
1008 \\
1009 \\
1018 \\
1404\end{array}$ \\
\hline Lake Trout & Salvelinus namaycush & SANA & $\begin{array}{l}1008 \\
1404 \\
1704\end{array}$ \\
\hline Brook Trout & Salvelinus fontinalis & SAFO & $\begin{array}{l}1007 \\
1008 \\
1009 \\
1012 \\
1018 \\
1019 \\
1404 \\
1405 \\
1601 \\
1704\end{array}$ \\
\hline Northern Pike & Esox lucius & ESLU & $\begin{array}{l}1012 \\
1018\end{array}$ \\
\hline Smallmouth Bass & Micropterus dolomieui & MIDO & $\begin{array}{l}1008 \\
1009 \\
1018 \\
1404\end{array}$ \\
\hline Largemouth Bass & Micropterus salmoides & MISA & $\begin{array}{l}1008 \\
1009 \\
1018 \\
1019\end{array}$ \\
\hline Green Sunfish & Lepomis cyanellus & LECY & $\begin{array}{l}1008 \\
1009 \\
1011 \\
1012 \\
1015 \\
1018 \\
1019\end{array}$ \\
\hline Bluegill & Lepomis macrochirus & LEMAC & $\begin{array}{l}1008 \\
1009\end{array}$ \\
\hline White Crappie & Poxomis annularis & POAN & $\begin{array}{l}1008 \\
1009 \\
1012 \\
1018 \\
1019\end{array}$ \\
\hline
\end{tabular}


APPENDIX A (Continued)

\begin{tabular}{|c|c|c|c|}
\hline $\begin{array}{c}\text { Species } \\
\text { Common Name }\end{array}$ & Scientific Name & $\begin{array}{l}\text { Species } \\
\text { Code }\end{array}$ & $\begin{array}{c}\text { USGS Basin } \\
\text { Subregion }\end{array}$ \\
\hline Black Crappie & Poxomis nigromaculatus & PONIG & $\begin{array}{l}1008 \\
1009 \\
1012 \\
1018 \\
1019\end{array}$ \\
\hline Walleye & Stizostedion vitreum & STVIVI & $\begin{array}{l}1008 \\
1012 \\
1018 \\
1019\end{array}$ \\
\hline Yellow Perch & Perca flavescens & PEFLA & $\begin{array}{l}1008 \\
1009 \\
1018 \\
1019\end{array}$ \\
\hline Tiger Muskellunge & Esox lucius X Esox masquinongy & $\begin{array}{l}\text { ESLU x } \\
\text { ESMA }\end{array}$ & 1018 \\
\hline Splake (trout) & $\begin{array}{l}\text { Salvelinus fontinalis } x \\
\text { Salvelinus namaycush }\end{array}$ & $\begin{array}{l}\text { SAFO } x \\
\text { SANA }\end{array}$ & $\begin{array}{l}1008 \\
1018\end{array}$ \\
\hline Ohrid Trout & Salmo letnica & SALET? & 1018 \\
\hline Carp & Cyprinus Carpio & CYCAR & $\begin{array}{l}1008 \\
1009 \\
1012 \\
1018 \\
1019 \\
1404 \\
1405 \\
1601\end{array}$ \\
\hline Emerald Shiner & Notropis atherinoides & NOAT & 1018 \\
\hline Flathead Catfish & Pylodictis olivaris & PYOL & 1018 \\
\hline $\begin{array}{l}\text { Rainbow/Cut throat } \\
\text { Hybrid }\end{array}$ & $\begin{array}{c}\text { Oncorhynchus mykiss } x \\
\text { Oncorhynchus clarki }\end{array}$ & $\begin{array}{l}\text { SAGA x } \\
\text { SACL }\end{array}$ & $\begin{array}{l}\text { See } \\
\text { Rainbow } \\
\text { Trout }\end{array}$ \\
\hline
\end{tabular}





